\title{
Synthesizing Scenario Planning and Industry Recipes through An Analysis of the Hollywood Film Industry
}

\author{
James Bezjian, The Citadel Military College of South Carolina \\ Baker School of Business \\ Bond Hall \\ 171 Moultrie Street \\ Charleston, SC 29409 \\ Tel: (843) 953-2405 \\ Email: jbezjian@citadel.edu \\ Veselina Stoyanova, University of Strathclyde \\ 16 Richmond Street \\ Glasgow, Scotland, G11XQ \\ Tel: +44 (0)141548 2834 \\ Email: veselina.stoyanova@strath.ac.uk \\ Peter McKiernan, University of Strathclyde \\ 16 Richmond Street \\ Glasgow, Scotland, G11XQ \\ Tel: +44 (0)1415524400 \\ Email: Peter.Mckiernan@strath.ac.uk \\ Brad MacKay, University of St Andrews \\ School of Management, \\ The Gateway, North Haugh, \\ St Andrews, Fife, Scotland, KY16 9RJ \\ Tel: +44(0)1334 463320 \\ Email: Brad.Mackay@st-andrews.ac.uk
}

\begin{abstract}
This paper creates a theoretical construct through the synthetization of industry recipes in the Hollywood film industry and scenario planning's intuitive logics approach. It illustrates how the incumbent-challenger paradox coupled with the industry recipes framework can provide a robust scenario narrative. Through a multiple case study approach, an industry recipe is constructed, the industry recipe factors are identified. Then the intuitive logics approach is blended with the industry recipe factors through the creation of scenario recipe factors and represented in a theoretical framework. The underlying premise of the paper purports that exploration of the industry recipes framework can help advance the intuitive logics approach through narrative development.
\end{abstract}

Running title: Synthesizing scenario planning and industry recipes

Keywords: Industry recipes; scenario planning; intuitive logics; industry recipe factors; scenario recipe factors 


\subsection{INTRODUCTION}

Scenario planning is a widely adopted strategy practice across firms (Schoemaker, 1995; Bradfield et al., 2005; Durance \& Godet, 2010; Amer, Daim \& Jeter, 2013). It is used commonly as a method to challenge the assumptions of managers (Varum \& Melo, 2010), and to interrogate the key uncertainties faced by decision-makers who are responsible for the strategic direction of a firm (Foster, 1993; Coates, 2000; Volkery \& Ribeiro, 2009). While a broad collection of methods for scenario planning are utilized, the intuitive logics (IL) approach is one widely accepted technique due to its use of rich narratives and prose used to outline potential evolutionary paths of the future (Wright, Bradfield \& Cairns, 2013; Derbyshire \& Wright, 2014; Derbyshire, 2017). The use of IL thinking can challenge insights, confront biases, and alter preconceived notions, creating improved decision-making environments for managerial foresight.

Scenario planning is an established approach for improving firm foresight; however, scholars have sought to further refine its methodological and theoretical underpinnings (McKiernan, 2015; Pereverza et al., 2017; Cairns \& Wright, 2018). For example, some scholars highlight that the cause-effect bias of the IL approach is single-faceted in nature and is ineffective in producing comprehensive scenarios for turbulent futures (Van der Heijden, 2000; Walsh, 2005; Burt, 2007). Thus, a shift into a multifaceted construct for the IL approach that helps to unify both theory and practice can contribute to a more comprehensive scenario narrative (Chermack, 2005; Bodwell \& Chermack, 2010; Wright et al., 2013; Derbyshire, 2017). Emerging research within scenario planning highlights an already growing body of literature that demonstrates a shift toward the use of theoretical constructs coupled with practitioner application (Bradfield et al., 2005; Van der Merwe, 2008; Varum \& Melo, 2010; Mackay \& Tambeau, 2013). Here, we postulate the industry recipes framework that is imbued with their own intuitive logics, can help advance IL techniques to scenario development.

In this article, we draw on notions of 'industry recipes' (e.g. Spender, 1989) to further augment and enhance the conceptual and practical breadth of the IL approach to scenario planning. Industry recipes are useful for understanding the essence of firm-to-firm interaction, which can produce different possibilities for how the future of a firm or its sector might unfold (Spender, 1989; Windeler \& Sydow, 2001; Chermack, 2017; Hadida \& Paris, 2014). We build on the work of prior scholars seeking to enhance scenario planning by developing a theoretical framework. This work highlights an area for exploration between IL contributors and the need for "salient causal linkage to participants" present viewpoints" (Derbyshire \& Wright, 2017: 255). We argue that industry recipe factors (IRF) provide analytical lens for focusing attention on key structural and behavioral interactions within industries that enable and constrain the possible scenarios that can emerge. This is particularly the case, we argue, with more focused industry scenarios (cf. Porter, 1985), which has received comparably less attention in the literature.

\subsection{Research aims, objectives, and purpose}

The aim of our article is thus to explore how notions of industry recipes can further enhance the IL approach. We therefore draw on concepts of industry recipes in the extant literature (e.g. Wendt, 1987; Spender, 1989; Archer \& Archer, 2003; Hodgson 2007) with the objective of synthesizing them within IL approaches to scenario planning, particularly as they pertain to 'industry scenarios' (e.g. Porter, 1985). To demonstrate their conceptual and methodological resonance with IL approaches, we focus specifically on contexts involving competitive rivalry with defined industries (cf. Chen \& Miller, 2015; Porter, 1985) between challenger and incumbent firms (Ferrier Smith \& Grimm, 1999; Smith Ferrier \& Grimm, 2001). More specifically, we attempt to deepen understanding of the role of industry recipes in causality in the IL scenario planning approach (Spender, 1989; MacKay \& Stoyanova, 2017). Such a synthesis may provide scenario-planners with an improved construct to enhance practitioner foresight in well-defined industry contexts. 


\subsection{Research questions, contributions, and structure}

The primary research question we address within this paper is, how might industry recipes, imbued with specific industry logics, help advance the IL approach to scenario development in competitive industry contexts? The paper therefore seeks to make three contributions to the literature on IL approaches to scenario planning. First, we contribute to the conceptual underpinnings of IL approaches to scenario planning by developing a theoretical framework combining industry recipe factors and the IL approach to scenario development. Second, by drawing on an in-depth inductive case study of incumbent and challenger firms in the Hollywood Film Industry, we contribute methodologically to IL approaches to scenario planning by demonstrating how drawing on industry recipe factors can enhance understanding of causality within intuitive logics. Finally, through our illustration of the theoretical and methodological enhancements to the IL approach to scenario development, we also contribute to the practice of scenario planning in competitive industry contexts by expanding the tool-kit available to practitioners.

Our paper is structured as follows. We begin with a conceptual overview of the IL approach to scenario planning and notions of industry recipes, arguing that industry recipe factors in contexts of competitive industry environments provide a useful lens for interrogating the causal drivers constraining and enabling the possible scenarios that can emerge. We then outline the research design for our inductive study into competitive rivalry between challenger and incumbent firms in the Hollywood film industry. Following our presentation of our findings pertaining to industry recipe factors in the Hollywood film industry, we turn to how such factors constrain and enable the emergence of alternative scenarios about how an industry can evolve, and we synthesize the framework with the IL approach to scenario development to demonstrate its perspicacity as a strategic foresight tool. Finally, we conclude this research by illustrating other research areas of exploration that may enhance scenario planning.

\subsection{CONCEPTUAL OUTLINE OF SCENARIO PLANNING, INDUSTRY RECIPES, AND EMPIRICAL OVERVIEW}

\subsection{Scenario planning and the intuitive logics approach}

In the present era of uncertainty and change in firms and industry milieus, the use of scenario planning has gained popularity as it offers an opportunity to create alternative pictures of how the future might unfold and to prepare for specific eventualities (Amer Daim \& Jetter, 2013). As a term in recent management and futures studies, scenario planning emerged from the work of Herman Kahn, initially at the RAND (Research and Development) Corporation, followed by the Hudson Institute (Varum \& Melo, 2010). Yet, its heritage is older and more widely spread geographically (see, for instance, MacKay \& McKiernan, 2018). Kahn and Wiener defined scenarios as "a hypothetical sequence of events ... for the purpose of focusing attention on causal processes and decision points" (1967: 6). These causal process and decision points provide a starting point for the scholarly interest of "scenarios-in-practice" (Wright, 2004: 4; also see Wack, 1985a, 1985b for a reflection on their successful application within Royal Dutch Shell). As a practitioner-oriented approach, scenario planning assist in formulating "wiser courses for the future" (Mason, 1994: 647).

One of the most common reasons for using scenarios in a firm's strategic planning process is to examine the potential impact of key uncertainties within an operating environment against a firm's strategic options (Burt \& Van der Heijden, 2003; Lindgren \& Bandhol, 2003; Ramirez et al., 2013). The application of scenario planning can also improve decision-making processes, challenge conventional thinking by reframing existing perceptions, and improve managerial understanding of the cause-and-effect sequences of how events might unfold in the future (Wright et al., 2013; Derbyshire \& Wright, 2017).

In this study, the focus is upon one of the most widely used approaches in scenario development -namely the intuitive logics (IL) approach. This is a descriptive, qualitative approach for constructing flexible 
scenarios by combining the imagination and critical thinking of participants (Wilkinson \& Kupers, 2014). It assists in determining the relationships between critical uncertainties (major driving forces of change) and trends (e.g. social, political, and technological), as well as the behavior of individual firms, who may have a stake in the particular future under study (Wright et al., 2013: 634). The underlying assumption is that future contexts are not pre-determined, but evolve through interactions between critical uncertainties and relatively predictable trends that are often embedded as behavioral or structural features of firm environments (see MacKay and Stoyanova, 2016). In turn, these are supported by assembled 'facts' from robust research. The process assembles such thinking and facts in a 'logical' way as illustrated by the cause and effect rollouts of major drivers and trends. These roll outs help provide a logical consistency and plausibility to the scenarios as they create credible alternative pathways of how the future might evolve. Intuition is woven into the process, for example, as judgements are made on the nature of trajectories after the bifurcated points of the roll outs.

The IL approach is a plausibility-based approach which assists in refocusing managerial attention on creating narratives which describe certain cause-affect relationships in the decision-making process in a given context (Mackay \& Tambeau, 2013). As it is based on cognition and likelihood, there are different variations when applying the intuitive logics approach. The IL approach assists in defining the key stakeholders, focal issues and horizon year by listing the key forces and trends, which could shape the future. During this process, the use of PESTEL ${ }^{1}$ analysis in combination with brainstorming activities helps to categorize of emerging forces, often through causal mapping and influence diagrams. Next, these forces can be further ranked according to their impact on shaping the future and divided into uncertain and 'forecastable' forces. A key advantage of IL approach is the development of a storyline showing the interactions between events that lead to a particular scenario.

\subsection{Industry recipes}

An industry recipe is, "part of a particular firm's response to the varying competitive conditions, work practices, technologies, public policies, legislation and so forth prevailing at the time" (Spender, 1989: 8). It is acknowledged as an adopted configuration of practices utilized by a firm and its rivals to produce similar products or services within a given environment (Spender, 1989; Spender, 2001; Bryman et al., 1996; Bierly \& Chakrabarti, 1999; Matthyssens et al., 2008; Sirmon \& Hitt, 2009; Hadida \& Paris, 2014). These firms deliver products and services for the business and consumer market they provide an industry classification that delineates direct and indirect competitors (Ferrier, Smith \& Grimm, 1999). Thus, the focus of our analysis in this research centers on the firms within the HFI and exploring how they great their products in the overall industry (Grinyer \& Spender, 2017; Monaghan \& Tippmann, 2018).

Recipes are an industry-wide framework that is interpreted at the firm level (Sabatier et al., 2010; Pettigrew, 1990; Verwater-Lukszo, 1998). Such a framework is comprised of industry recipe factors. These are defined as the critical components that complete a recipe (Spender, 1996). These can be actions or developed products that contribute to the completion of the overall recipe (Spender, 1989; Galvin et al., 2004; Monaghan \& Tippmann, 2018). For example, in the HFI, 3D digital animation software is a critical ingredient to create an animated feature film. Thus, the software is a factor that contributes to the overall recipe. Such factors are directed by managers responsible for decision-making, resourcing, and quality control to maintain the integrity of those actions and product components. Additionally, "values encompass those deep-seated perceptual and cognitive representations of social normative beliefs, empathic feelings, motives and needs that drive actions and behaviors" (Sarpong et al., 2013: 620). These actions are imbued through an "organization's activity and directed toward specific objectives established through the policy-

\footnotetext{
${ }^{1}$ PESTEL is a tool used by marketers and strategists to help identify drivers and shapers of change. The letters stand for Politics, Economics, Socio-demographics, Technology, Environment and Legal issues.
} 
setting process" (Grinyer \& Spender, 1979: 113). Thus, an industry recipe possesses its own intuitive logics represented by what is taken-for-granted in the industry, and manifests in managerial actions and competitive behavior (Burke \& Miller, 1999; Dane \& Pratt, 2007; Dunn et al., 2010; Messner, 2016). These actions enacted by managers can affect the firm's strategic direction and influence its position among its direct and indirect rivals within an industry (Porter, 1996; Heracleous, 1998; Andersen, 2004). It is through such actions by challenger firms and incumbents that competitive rivalry is shaped, and ultimately, influences how an industry evolves, often in surprising directions, over time. (Matthews, 2002; Sandstrom et al., 2009; Vecchiato, 2017).

Incumbent firms within the industry are defined as recognized or established entities that supply, mold, and shape the industry recipe. These firms control the majority of the resources necessary to maintain market leadership within the industry. Challenger firms within an industry are classified as contemporary and new entities that seek to contest segments and perhaps replace or revise the dominant recipe. They strive to redefine the status quo through entrepreneurial engagement with the recipe within the industry. Such activity can reveal the intuitive logics behind the industry recipe as a whole (Van der Heijden, 2000; Giddens, 2013; Baden-Fuller \& Mangematin, 2013).

There is a scarcity of research studies exploring the relationship between industry recipes and scenario planning. Thus, we seek to understand the how these domains might inter-relate and whether such a synthesis might provide managers with improved tools to better understand how the industry might evolve.

\subsection{Empirical context and background of the study}

Our empirical context centered around two significant factors. The first involved choosing an industry with an established track record of a well-known product offering. Emerging markets could not be utilized due to the ambiguity of a formed industry recipe and the need to illustrate the associated relationship between industry recipes and scenario planning. Thus, following these two prerequisites, and after a wide-ranging search, the Hollywood film industry was selected as an adequate empirical context for this study.

The Hollywood Film Industry emerged as a trade craft of Broadway plays in New York during 1902 (Ross, 2001). As the trade grew in popularity, filmmaking migrated west and a standardized feature film production was established in 1922, making Hollywood, California, the entertainment capital of the country (Morey, 2003; Trumpbour, 2007). The standardization of feature films gave rise to firms' specializing in feature film development known as motion picture studios. These major motion picture studios emerged as one-stop creative hubs for feature film development, controlling the writing, financing, producing, marketing, and distribution of feature films throughout the United States and around the world (Lorenzen, 2007, 2008). Hollywood motion pictures became a cultural phenomenon and grew in popularity, experiencing a massive rise in revenue and influence (Trumpbour, 2007). The U.S. Supreme Court took note of the centralized control Hollywood film industry and ordered its decentralization in 1948 (Gil, 2010). The action caused the emergence of trades, guilds, and unions within the entertainment industry. They formed after splitting off as separate entities for the studios and carved out a new market segment within the industry. Similarly, one of these market segments involved technology. Technology developed over time and gave rise to secondary markets within the Hollywood film industry contributed to portions of the feature film creation process through resource acquisition and development. The Hollywood film studio's use of these secondary markets became necessary to the survival, continuity, and evolution of the overall industry.

\subsection{RESEARCH DESIGN, METHOD, AND ANALYSIS}

\subsection{Designing the research}


The adopted research design is positioned to: a) construct a recipe framework for a mature industry; and, b) synthesize the domains of intuitive logics in scenario planning with the industry recipes framework. We frame this through the lens of incumbent and challenger firms vying for market share within the HFI.

\subsection{Determining the methodological approach}

The favored methodological pathway for this study was a multiple case design. Evidence is gathered, assessed, interpreted, and documented across several independent case studies. Multiple cases provide a wider array of information to gather and examine as opposed to a single case study that provides a sole perspective within an entire industry (Eisenhardt, 1989; Yin, 2003). When multiple case studies are compared, literature can be used to support or reject research assertions (Vannoni, 2015). Additionally, Baxter and Jack (2008) argue that the data and insight generated from a multiple case study approach can be grounded and dependable. Further, a multiple case study approach provides an opportunity for extensive scholarly inquiry into the proposed research questions (Eisenhardt \& Graebner, 2007). The method is described as a four-phase process below.

\subsubsection{Phase 1: Documenting and gathering empirical evidence}

The first step involved the gathering of documentation and information through open source networks to learn about the HFI and help determine the case studies for selection. The researchers gathered materials associated with the creation, development, and deployment of feature films. This included press releases, annual reports, project estimations, internal memorandums, strategic plans and notes provided by the interviewees. Project estimations played an important role in understanding how firm specific leadership perceived product development and creation. Moreover, internal memos provided insight regarding managerial viewpoints of consumer attitudes toward upcoming projects and collaborations. Additionally, strategic plans and annual reports demonstrated a detailed outlook of managerial actions and highlighted potential future trends. These trends provided the researchers with insight regarding firm-specific perceptions relative to the incumbent challenger paradigm and the future positioning of the firm and industry as a whole. Further, industry-specific interviews were conducted with managerial elites from established and challenger studios and detailed data sets about the HFI. Additional information such as financial reports, product performance reports, and business proposals were deciphered and structured into a excel framework used for case selection and interview participants.

\subsubsection{Phase 2: Selecting the cases}

After the collation of data in phase one, four case studies were selected to represent the incumbent and challenger firms based upon industry structure and researcher accessibility. The Hollywood firms are notoriously secretive and often disinclined to participate in studies external to the industry. Thus, accessibility is a key determinant for sample inclusion. Even then, firms only agreed to participate in the research under circumstances of anonymity.

Centering on the need to represent the industry proportionally, "the incumbent/challenger distinction has long been a conceptual staple of social movement theory" (Fligstein \& McAdam, 2011:5). Thus, incumbent firms are institutions that control large resources, supplier pricing, have access to financial assistance and control critical technology necessary to produce their products (Pfeffer \& Salancik, 1978; Burt, 1983; Fligstein, 1996; Ferrier et al., 1999; Vakratsas \& Ma, 2009; Ansari \& Krop, 2012). These firms are, "constantly trying to edge one another (and challengers) out for market share, but they refrain from direct confrontation that might prove the ruin of all" (Fligstein, 1996: 667). They focus on other incumbents and disregard the actions of challenger firms while trying to maintain the current status quo of the industry (Fligstein, 1996: 667). Additionally, "challenger firms are smaller and frame their actions in terms of the largest firms" (Fligstein, 1996: 663). They possess a significantly smaller pool of resources, are subject to 
supplier pricing. These firms, "challenge the existing order" while incumbents, "confront them and attempt to reinforce the governing conception of control" (Fligstein 1996: 667). Using Fligstein's framework, two incumbent and two challenger studios were selected for this study. The researchers collected descriptive data on: the founding date of the firm, number of employees, resource accessibility, totality of in-house production, and finally distribution capacity. This data was used to classify each studio represented in Table 1 .

Insert Table 1 about here.

\section{a) Incumbent major studio (IMaj)}

IMaj was selected due to its emergence from the formation of the industry. It is considered a 'Big Five' firm and it has nearly a century of history and interaction with the Motion Picture Association of America. The firm's presence is well known throughout the industry and significantly contributes to the proliferation of Hollywood entertainment. It is classified as an incumbent major studio due to its market share of feature films, the total size of the firm and the number of retained employees. The long history of film production continued into the 21 st century with an average of 15-20 films being produced each year. IMaj retains a substantial studio lot in Los Angeles, utilizing their resources to create, finance, produce, market, and distribute their film properties throughout the world.

\section{b) Challenger major studio (ChMaj)}

ChMaj was selected due to its sudden rise within the industry. With limited resources and significant brand recognition, this studio became a major competitor among the incumbent firms due to targeted technological resource acquisition. The firm is significantly smaller than its rivals but, it enjoys a robust employee retention count. Due to its restricted resources, the firm outsources segments of the feature film production to stay competitive within the industry. Additionally, this studio's strategic focus was on a growing consumer niche market. ChMaj releases 3-6 films a year.

\section{c) Incumbent minor studio (IMin)}

IMin was selected due to its growing influence throughout the Hollywood industry. This firm has enjoyed rapid brand recognition due to the acquisition of popular intellectual properties. It has a strong reputation in the industry of live-action film development. These properties were well received as feature films. Despite its growing popularity, the firm is limited in size, scope, and resources. It participates in cofinancing deals on film projects and must outsource its marketing and distribution to third party affiliates. The firm produces 13-15 feature films a year and for that reason, it is identified as an incumbent minor studio.

\section{d) Challenger minor studio (ChMin)}

ChMin was selected and classified for its limited size and scope in the industry. Additionally, the studio has carved out a niche audience for its' films. The studio classification also indicates limited firm control of assets and resources. Its primary resource resides is its intellectual property and ability to acquire scripts. 
While the firm may get access to high profile properties, they must partner and co-produce to see those properties transpire into film. ChMin creates and distributes 4-5 feature films a year. The firm employs 10 people and has personnel that's involved in all aspects of the development of feature films.

\subsubsection{Phase 3: Conducting a survey}

The survey was conducted to better understand the managerial perspective of the industry relative to the represented firm. To conduct a survey among executive elites required preparation on situational awareness, power dynamics, the establishment of rapport with the interviewees; and, the maintenance of the attention of interviewees throughout the course of the survey (Singleton \& Straits, 2002; Secor, 2010; Rowley, 2012). Hollywood authorities across the industry were consulted to assist with the creation of the survey and development of the interview questions so, interviewees understood the questions relative to their case. Industry experts included: a former Chairman and CEO of a major firm, the vice president of production for a major firm, Senior Vice President for Branding and Marketing Strategy at a major firm, Senior Director of Finance at a minor firm, and the Senior Director of Production at a minor firm. These industry experts tested the questions before they were distributed to the participants to guarantee consistency and clarity. The survey comprised of five detailed questions concerning industry structure and film creation. The survey questions can be found in Table 2 within the appendix. Once the survey was complete, the questions served as a reference for the interview questions posed to the interview participants.

\subsubsection{Phase 4: Performing the interviews}

Once the case selection and survey were complete, the interview process was initiated with the case study participants from each studio (Leech, 2002; Longhurst, 2003). Three studios provided eight executives for interview, and the fourth studio provided six. The total interview participant count was thirty. The interviews were semi-structured in nature, lasting forty to ninety minutes each (Newcomer et al., 2015). All interviews were recorded, with the exception of one which was documented through detailed note taking. The interviews were conducted between January 2015 and January 2016. Profiles of the interviewees can be found in Table 3.

Insert Table 3 about here.

The interview questions provided an opportunity for interviewees to produce a detailed description of the industry recipe factors and industry recipe as it relates to their designated firm. Interviews were transcribed and returned to the interviewees for authentication in order to improve accuracy of the interviews and to decrease the chance of misconstrued information. The data collected through our interviewing process allowed for a comprehensive case analysis, outlined in the following section.

\subsection{Analysis and scenario drivers}

The data analysis was broken into two phases to ensure continuity in design and application. In phase one, interview data was clustered into categories based on the functionality of the movie-making process. Following the model of Spender (1989), we illustrate how the industry recipes framework was created. 
Using open coding for each case, we conducted our analysis using SPSS Text Analytics. We deciphered the industry recipe paradigm within the Hollywood Film Industry adopted by both incumbent and challenger firms through pattern behavioral coding. This centered on an interpretive understanding of the particular factors recognized across the firms engaged with feature film production. To compare the interpretations of feature film development, the codes were assembled into clusters centered on similarities and differences (Huberman \& Miles, 2002). Codes containing comparable interpretive understanding were clustered together to create the first order categories that would ultimately create the market interpretation of the overall industry recipe. We verified the interpretation across the four case studies, ensuring continuity.

Phase two involved following the same steps as phase one. However, the focus centered on how industry recipe factors were deployed through the incumbent challenger firm classification paradigm (Ferrier et al., 1999). Similar to phase one, responses were separated into themes and organized as first order groupings. Once the second study was complete, similarities were sought between the two analysis and second order themes emerged. These second order themes generated a greater connection between the perceptions of the industry recipe relative to incumbent challenger paradigm within the market. For example, themes such as intuition, logic, and development emerged from the analysis involving the creation of feature film development. Then, we created a duplication logic model to authenticate the recipe factors across the four cases and generated themes. The final stage of analysis involved the creation of an empirical framework describing the observed patterned behavior and interconnectedness between the industry recipe and the industry recipe factors among the incumbent challenger paradigm (Hammersley, 1989). We validated our framework through a final iterative refinement of the data.

\subsection{FINDINGS}

In this section, we identify the industry recipe factors necessary for the creation of a Hollywood film industry recipe and elaborate on the relationship between industry recipes and the intuitive logics process of scenario planning.

\subsection{Integrating of industry recipes}

All four studios were found to share several industry-wide recipe factors. Those factors included: the sourcing of intellectual property (IP), the procurement of financial resources, the production of the property, marketing of the feature film, and distribution of the project. The recipe factors and procedure are depicted in Figure 1 below.

Insert Figure 1 about here.

While the firms recognize and accept the industry adopted framework, each firm utilizes the recipe factors in a distinctive fashion based on their market position and goals. First, a studio must source or develop and intellectual property. Once the property is solidified in the form of a script, it is debated and discussed

within the "green-lighting" process of the studio. The green-lighting process unites the aspects of the 
industry recipe within one room to provide estimates, projections, and analysis regarding the potential financial performance of the project. Once the final budget is approved and funding is supplied, the film begins production, with the director/producer providing the artistic vision of the film. This creative process is known as production. The production teams are brought together, and the movie is shot on film and assembled through post-production.

During the post-production process, marketing and distribution teams are united to discuss the best strategy for the film within the domestic and international regions. Each recipe factor has a unique purpose among incumbent and challenger firms. The positional classification of a firm can affect whether a recipe factor is a strength or weakness throughout the film development process. An incumbent firm's primary recipe factor strength involves its access to noteworthy scripts and intellectual property, along with financial and distribution resources. While other recipe factors, such as production and marketing, are effective throughout the incumbent studio recipe, they would not be classified as a strength due to the limited time and energy invested in the process. A challenger firm's recipe factor strength is in its production and marketing capability. Likewise, intellectual property sourcing, financial procurement, and distribution among challenger firms is a weakness due to the need to continually procure resources to effectively deploy the recipe factors. Given the incumbent challenger position of each firm and the recognized strengths and weaknesses of each industry recipe factor, each factor is a sub-categorical industry in itself. Thus, the industry recipe factors provide a fertile field of research regarding the intersection of recipes and scenario planning.

\subsection{The interplay of industry recipe factors}

The firm's industry has a bearing on how a recipe is tailored and deployed (Porter, 1980). Industry recipe factors (IRF) were the most cited topic throughout the interviews. Respondents explained how aspects of IRFs significantly impacted upon the success or failure of a feature film. Aspects such as distribution deals, marketing campaigns, and production quality all had a bearing on the success or failure of a film. When analyzing IRFs among firms, IMaj and IMin share the need for accurate financial forecasting. Incumbent firms place significant emphasis on financial performance because it represents a direct correlation of market share penetration, ultimately determine how to maximize financial performance in a competitive environment (Porter, 1980). Additionally, industry incumbents seek to maintain control while challengers try to dethrone the incumbents during times of transformation, disruption or uncertainty (Porter \& Rivkin, 2000; Foss, 1997). Conversely, ChMaj and ChMin do not share any commonly emphasized IRFs, because the challenger firms focus on a niche market in the feature film industry. Since ChMaj is a challenging major firm, it stresses the need for effective marketing campaigns to establish brand awareness. ChMin has a need to procure financing due to its small size. Comparatively, IMaj and ChMaj compete with one another. IMaj uses its financial resources and access to intellectual property. Likewise, ChMaj utilizes channels of relationships to develop unique intellectual properties to compete with IMaj. Their marketing channels provide a robust network of resources that build brand awareness for their properties. Within the minor firm rivalry, accurate financing and access to financial revenue is the main driver. IMin competes for financial resources as well as positioning for growth to become a major firm. Similarly, ChMin seeks financial resources to gain legitimacy within the industry. IMin has already established legitimacy as a significant firm player within the industry; the firm is continually trying to grow to rival its major firm competitors.

\subsection{SYNTHESIS}

\subsection{Synthesizing industry recipes and IL approaches to scenario planning}


This research had a single principal objective which was to further explore how the intuitive logics (IL) approach can be linked to the industry recipes framework. Additionally, our researched asked, how might industry recipes, imbued with specific industry logics, help advance the IL approach to scenario development in competitive industry contexts? In this section we suggest an emerging theoretical framework examining a relationship between the IL approach and industry recipes.

Insert Figure 2 about here.

A scenario planning projects pivotal aspect of influence is perceived by the level of 'purpose' the project provides (Bradfield et al., 2002: 806; Van der Heijden et al., (2002). Purpose can be defined within two pathways: 1) one-off needs or long-term planning; and, 2) innovative exploration of the future or understanding of a prior phenomenon (Bradfield et al., 2002). Utilizing the industry recipes framework could satisfy both aspects of scenario planning. Establishing the industry recipe configuration provides a social construct surrounding intuitive perception and managerial knowledge among the incumbent challenger paradox portrayed in Figure 2. Using industry recipes provides a way of framing the various stages of the IL approach. The classification illustrates "clues as to the types of causal relationships that will tend to continue into the future in the focal system of influences" (Derbyshire \& Wright, 2017: 261). Therefore, the industry and its firms, classified as incumbent and challengers, are incorporated in the scenario context. Figure 3 outlines this specificity through the establishment of the HFI recipe. It highlights the various factors adopted by all industry members regarding the development of a feature film. To further explain the synthetization process, we break down a Harvard Business Case study that illustrates how animated feature films evolved within an industry within an IRF (Barthélemy, 2011). The IRF used within the case study is represented in Figure 3, labeled as IRF 3.

Deciphering an industry recipe and the firms within the structure during Stage 1 of IL integrates "the examination of historical change and its causes" (Derbyshire \& Wright, 2017: 262) through both an industry-wide platitude and firm specificity. Thus, establishing the IRFs of an industry from their historical account can contribute to the development of potential IRF evolution. Hence, the animated production process of feature films consists of artists, script writers, musical composers, voice actors, and specified animation artists skilled at compiling and assembling a plethora of pieces to create an animated feature film. In the early 1990s, that all changed when digital animation and technology became the artistic backbone for the industry.

Stage 2 of the IL approach highlights drivers and emerging forces among incumbent and challenger firms. Utilizing the PESTEL dimensions as a guide within the industry, the IRFs provide a structure to understand evolutionary activities on an industry- and firm-specific level. For example, if a scenario strategist conducted a scenario of animated feature film production in the 1990s, the use of frameworks like PESTEL could identify the dimension with the strongest impact on the IRF. The IRFs contextually frame the separate driving forces to provide a recipe factor specific scenario narrative. Figure 3 illustrates how the HFI IRFs can integrate the IL approach for contextually specific narrative development.

Insert Figure 3 about here. 
Stage 3 commences once the PESTEL process is complete and the clusters of information are assembled into driving forces. A scenario strategist would focus on elements of the IRF production and analyze the elements around producing animated feature films. Using the digital animation example previously presented, a PESTEL might indicate technology as a significant driving force for animated feature film production. With the PESTEL driver identified, scenario strategists would begin assembling the narrative for the IRF. The narrative classification for IRFs consists of classifying emerging forces via causal mapping and influential diagrams. Thus, these depictions illustrate how technological developments in other industries can influence the IRF production of animated feature films.

Stage 4 involves the creation of plausible sets of scenario results for each IRF. The information is arranged into two sets of outcomes for the corresponding IRF. The animated feature film production example provides the basis for the two scenario outcomes. The first outcome involves a total shift in production development, where digital technology becomes the dominant tool for animated feature film development. It replaces prior methods as the preferred tool of the trade. The second involves digital technology becoming a novelty for animated feature films, adding to the portfolio of tools rather than being the dominant tool. Thus, it acts as a chain in the technological evolutionary process, with no real significant market impact.

Stage 5 profiles each scenario outcome as: a) extreme impact on a specified issue; and b) a high degree of uncertainty. Using the presented example above, the first scenario is extreme, with impacts on production development and infrastructure, as well as uncertainty surrounding revenue generation. The first scenario symbolizes a total shift in resource, resource and capability assembly, and product development. It highlights the need for producing top quality work and the necessary action required to develop and implement the right resources. The second scenario illustrates a minor impact, with a need to justify high substantial investment costs with an unknown revenue model. It draws upon the example that the technology will be desired, but factors in the unknown demand of the new technology. Both narratives are derived as a SRF and represented in Figure 3.

Stage 6 involves the appraisal of the presented scenario outcomes by exploring their potential narrative. Thus, the SRF frames the narrative through the decision-making paradigm of executive leadership within a studio within the animated feature film segment. Assuming the scenarios were modeled in the 1990s per the case study example, one could argue that adoption of the first scenario outcome would require new resources, both technological and human. Additionally, it would require a substantial investment made on the part of the adopting firm. The investment would need a financial justification and integrated pricing scheme that would help generate revenue. Conversely, adoption of the second scenario would require an adequate price point for the absorption of technology within the firm. Additionally, executives would need a specified niche market that possessed the purchasing power and acquired taste for such a product. Once the possible outcomes and SRF storyline are established, implementation of the SRF can begin.

In summary, within industry scenarios, SRFs reflect the key logics that are both the bases of continuity within an industry's evolution, and through the interactions of incumbents and challenger firms, they draw attention to the key uncertainties leading to unexpected industry change. They draw attention to the key, often taken-for-granted drivers of an industry, but also how the competitive behaviors and dynamics of incumbents and challengers disrupt them in unexpected ways. 


\subsection{CONCLUSION}

This paper was developed with the objective to explore and understand the relationship between industry recipes and scenario planning through an IL perspective. Industry recipes are recognized as adopted patterns implemented by a group of firms that form a framework of production for a specific product or service (Spender, 1989; Phillips, 1994; Skule, 1996). Thus, the participants within a firm influence the "business specific world view of a definable 'tribe' of industry experts, and is often visibly articulated into the rituals, rites of professional passage, local jargon and dress" (Spender, 1989: 7). These "tribes" of experts help to create and ingrain intuitive logics within their adopted industry recipe. Moreover, an industry recipe could be positioned to provide purposeful meaning through narrative development. Thus, IRFs provide pathways of scenario planning narratives of "plausible future states" of the industry, current or previous phenomena, and one-off events, "to consider how to take advantage of opportunities and avoid potential threats" and conceptualize the future (Miller \& Waller, 2003: 93).

To build synergies between both domains, we drew on the industry recipes framework, and classified each case as an incumbent or challenger firm. Additionally, we sought to interpret the industry recipe of the HFI by administering a survey and completing 30 semi-structured interviews across all four cases. After processing the data, we deciphered the HFI IRFs and reconciled the IL approach with each IRF, creating a new sub-category for scenario narrative development known as a Scenario Recipe Factor (SRF). The SRF represents categories for narrative production for each IRF among the overall HFI industry recipe. It underscores how aspects of the industry can be categorized to explain industry-wide phenomena, one-off events, or exploration surrounding possible futures. Our contribution links a conceptual framework with the IL approach to further understand how to enhance the IL approach for scenario planning.

\subsection{Contributions to theory \& practice}

Our paper makes three contributions to theory and practice. The first contribution is developing the concept of scenario recipe factors through a synthesis of industry recipe factors and the intuitive logics approach to scenario planning, and specifically, to industry scenarios (cf. Porter, 1985; Rivkin and Porter, 2000). It provides executives within firms with a scenario-based tool for understanding competitive dynamics within industries as they relate to industry recipes and the disruption of those recipes through firm interactions (e.g. Chen and Miller, 2015). It therefore also extends the behavioral foundations of the intuitive logics approach to scenario planning (cf. Schoemaker, 1993). Second, the paper contributes to the methodology of scenario planning by using the concept of SRFs as a lens for analyzing causality by focusing on the recipes that, we suggest, underpin scenario drivers and their disruption (e.g. Spender, 1989). Third, for practitioners, synthesizing industry recipes and scenario planning can empower a firm to take the necessary actions to accelerate evolutionary forces to shift or change the recipe of an industry despite their position. The use of scenarios on an industry-wide level may expose practitioners to resources external to the immediate industry that provides a strategic advantage in one or all of the recipe factors. Practitioners can thus use this framework as a planning tool to develop business intelligence units that craft and develop scenarios to compete amongst rivals within an IRF. Incumbents recognize IRFs as the framework to success; thus, disruption among one IRF can have drastic implications for all. Likewise, challenger firms can shift IRF development to disrupt the overall industry as a means to remove a rival and increase market share. The use of scenario strategies through the form of SRFs provides perspective on managerial foresight and strategic positioning.

\subsection{Limitations \& future research}

There are several limitations to this study. First, our case study selection was dependent on the willingness of executives to participate, as the industry has a reputation for being highly secretive. Thus, our given sample set represents a portion of the overall industry and is non-random thus, major generalization to the 
rest of the HFI is not possible. But, the access and information achieved was invaluable as an eye opener to a very private industry. Obtaining a larger sample set of cases throughout the industry could provide a more robust explanation of the dynamics behind the nuances of the HFI. Second, the new framework was only applied in a mature industry. Emerging industries were disregarded due to the structural context necessary to construct scenario narratives at the firm level. Further examination in these industries might yield a different interaction between IL and IR that is difficult to predict from this study alone.

In this research, we develop a line of inquiry emerging from both the scenario planning literature and industry recipe literature. We synthesize an industry-based theory with a scenario planning approach to create a framework for practitioner-based scenario planning narratives. Further research opportunities are possible through advanced narrative development by an in-depth analysis of industry factors. Additionally, relating the industry recipe framework and IL approach with the agent-structure paradox can help scholars further understand the relationship between a created structure and the IL approach. Furthermore, analysis of supplemental industries would corroborate or refute the theoretical model, for example: how can narratives be further developed within the IL approach and industry recipes? What aspects of the IL approach can integrate into the managerial decision-making process of an industry recipe? Finally, further development surrounding the relationship between IRFs and the IL approach can improve scenario narrative development.

\subsection{ACKNOWLEDGEMENTS}

The authors would like to thank the editors and two anonymous reviewers for their guidance and support throughout the development of this paper. 


\subsection{REFERENCES}

Amer, M., Daim, T. U., \& Jetter, A. (2013). A review of scenario planning. Futures, 46, 23(40).

Andersen, T. J. (2004). Integrating decentralized strategy making and strategic planning processes in dynamic environments. Journal of Management Studies, 41(8), 1271-1299.

Ansari, S. S., \& Krop, P. (2012). Incumbent performance in the face of a radical innovation: Towards a framework for incumbent challenger dynamics. Research Policy, 41(8), 1357-1374.

Archer, M. S., \& Archer, M. S. (2003). Structure, agency and the internal conversation. Cambridge University Press.

Baden-Fuller, C., \& Mangematin, V. (2013). Business models: A challenging agenda. Strategic Organization, 11(4), 418-427.

Barthélemy, J. (2011). The Disney-Pixar relationship dynamics: Lessons for outsourcing vs. vertical integration. Organizational Dynamics, 40(1), 43-48.

Baxter, P., \& Jack, S. (2008). Qualitative case study methodology: Study design and implementation for novice researchers. The Qualitative Report, 13(4), 544-559.

Bierly, P., \& Chakrabarti, A. K. (1999). Managing through industry fusion. In The Dynamics of Innovation (pp. 3-26). Springer, Berlin, Heidelberg.

Bodwell, W., \& Chermack, T. J. (2010). Organizational ambidexterity: Integrating deliberate and emergent strategy with scenario planning. Technological Forecasting and Social Change, 77(2), 193-202.

Bradfield, R., Wright, G., Burt, G., Cairns, G., \& Van der Heijden, K. (2005). The origins and evolution of scenario techniques in long range business planning. Futures, 37(8), 795-812.

Bryman, A., Gillingwater, D., \& McGuinness, I. (1996). Industry culture and strategic response: The case of the British bus industry. Studies in Cultures, Organizations and Societies, 2(2), 191-208.

Burke, L. A., \& Miller, M. K. (1999). Taking the mystery out of intuitive decision making. Academy of Management Perspectives, 13(4), 91-99.

Burt, G. (2007). Why are we surprised at surprises? Integrating disruption theory and system analysis with the scenario methodology to help identify disruptions and discontinuities. Technological Forecasting and Social Change, 74(6), 731-749.

Burt, G., \& Van der Heijden, K., (2003). First steps: towards purposeful activities in scenario thinking and future studies. Futures 35, 1011-1026.

Cairns, G., \& Wright, G. (2018). Advanced Methods in Scenario Development: Uncovering Causality and Using the Delphi Method. In Scenario Thinking (pp. 141-154). Palgrave Macmillan, Cham.

Chen, M-J., \& Miller, D. (2015). Reconceptualizing competitive dynamics: A multidimensional framework. Strategic Management Journal, 36: 758-775.

Chermack, T. J. (2005). Studying scenario planning: Theory, research suggestions, and hypotheses. Technological Forecasting and Social Change, 72(1), 59-73.

Chermack, T. J. (2017). Foundations of scenario planning: The story of Pierre Wack. Routledge.

Coates, J. F. (2000). Scenario planning. Technological Forecasting and Social Change, 65(1), 115-123. 
Dane, E., \& Pratt, M. G. (2007). Exploring intuition and its role in managerial decision making. Academy of Management Review, 32(1), 33-54.

Derbyshire, J. (2017). Potential surprise theory as a theoretical foundation for scenario planning. Technological Forecasting and Social Change, 124, 77-87.

Derbyshire, J., \& Wright, G. (2014). Preparing for the future: development of an 'antifragile' methodology that complements scenario planning by omitting causation. Technological Forecasting and Social Change, 82, 215-225.

Derbyshire, J., \& Wright, G. (2017). Augmenting the intuitive logics scenario planning method for a more comprehensive analysis of causation. International Journal of Forecasting, 33(1), 254-266.

Dunn, B. D., Galton, H. C., Morgan, R., Evans, D., Oliver, C., Meyer, M., \& Dalgleish, T. (2010). Listening to your heart: How interoception shapes emotion experience and intuitive decision making. Psychological Science, 21(12), 1835-1844.

Durance, P., \& Godet, M. (2010). Scenario building: Uses and abuses. Technological Forecasting and Social Change, 77(9), 1488-1492.

Eisenhardt, K. M., \& Graebner, M. E. (2007). Theory building from cases: Opportunities and challenges. Academy of Management Journal, 50(1), 25-32.

Eisenhardt, Kathleen M. (1989). Building theories from case study research. Academy of Management Review 14(4), $532-550$.

Ferrier, W. J., Smith, K. G., \& Grimm, C. M. (1999). The role of competitive action in market share erosion and industry dethronement: A study of industry leaders and challengers. Academy of Management Journal, 42(4), 372388.

Fligstein, N. (1996). Markets as politics: A political-cultural approach to market institutions. American Sociological Review, 656-673.

Fligstein, N., \& McAdam, D. (2011). Toward a general theory of strategic action fields. Sociological Theory, 29(1), $1-26$.

Foss, N. J. (Ed.). (1997). Resources, firms, and strategies: a reader in the resource-based perspective. Oxford University Press on Demand.

Foster, M. J. (1993). Scenario planning for small businesses. Long Range Planning, 26(1), 123-129.

Galvin, T. L., Ventresca, M. J., \& Hudson, B. A. (2004). Contested industry dynamics. International Studies of Management \& Organization, 34(4), 56-82.

Gil, R. (2010). An empirical investigation of the Paramount antitrust case. Applied Economics, 42(2), 171-183.

Giddens, A. (2013). New rules of sociological method: A positive critique of interpretative sociologies. John Wiley \& Sons.

Grinyer, P. H., \& Spender, J. C. (1979). Recipes, Crises, and Adaptation in Mature Businesses. International Studies of Management \& Organization, 9(3), 113-133.

Grinyer, P. H., \& Spender, J. C. (2017). "Stream of Events" is evidence of a plan. (1) When there is no. Historical Evolution of Strategic Management, Volumes I and II, 1, 247. 
Hadida, A. L., \& Paris, T. (2014). Managerial cognition and the value chain in the digital music industry. Technological Forecasting and Social Change, 83, 84-97.

Hammersley, A. P., \& Riekel, C. (1989). MFIT: Multiple spectra fitting program. Synchrotron Radiation News, 2(1), $24-26$.

Heracleous, L. (1998). Strategic thinking or strategic planning?. Long Range Planning, 31(3), 481-487.

Hitt, M. A., \& Tyler, B. B. (1991). Strategic decision models: Integrating different perspectives. Strategic Management Journal, 12(5), 327-351.

Hodgson, G. M. (2007). Institutions and individuals: interaction and evolution. Organization studies, 28(1), 95-116.

Huberman, M., \& Miles, M. B. (2002). The qualitative researcher's companion. Sage.

Kahn, H., \& Wiener, A., 1967. The Year 2000, a Framework for Speculation. MacMillan, New York.

Leech, B. L. (2002). Asking questions: Techniques for semi structured interviews. PS: Political Science \& Politics, 35(4), 665-668.

Lindgren, M., \& Bandhold, H. (2003). Scenario Planning. Palgrave.

Longhurst, R. (2003). Semi-structured interviews and focus groups. Key methods in geography, 3, 143-156.

Lorenzen, M. (2007). Internationalization vs. globalization of the film industry. Industry and Innovation, 14(4), 349357.

Lorenzen, M. (2008). On the globalization of the film industry. Creative Encounters Working Paper.

MacKay, R. B., \& Stoyanova, V. (2017). Scenario planning with a sociological eye: Augmenting the intuitive logics approach to understanding the Future of Scotland and the UK. Technological Forecasting and Social Change, 124, 88-100.

MacKay, B., \& Tambeau, P. (2013). A structuration approach to scenario praxis. Technological Forecasting and Social Change, 80(4), 673-686.

Martelli, A., 2001. Scenario building and scenario planning: state of the art and prospects of evolution. Futures Research Quarterly, 17(2), 57-74.

Mason, D.H. 1994. Scenario-based planning: Decision model for the learning organization. Planning Review, 22.611.

Matthews, J. A. (2002). A resource-based view of Schumpeterian economic dynamics. Journal of Evolutionary Economics, 12(1-2), 29-54.

Matthyssens, P., Vandenbempt, K., \& Berghman, L. (2006). Value innovation in business markets: Breaking the industry recipe. Industrial Marketing Management, 35(6), 751-761.

Matthyssens, P., Vandenbempt, K., \& Berghman, L. (2008). Value innovation in the functional foods industry: Deviations from the industry recipe. British Food Journal, 110(1), 144-155.

McKiernan, P. (2015). Scenario planning. Wiley Encyclopedia of Management, 1-4.

Messner, M. (2016). Does industry matter? How industry context shapes management accounting practice. Management Accounting Research, 31, 103-111. 
Miller, K. D., \& Waller, H. G. (2003). Scenarios, real options and integrated risk management. Long Range Planning, 36(1), 93-107.

Monaghan, S., \& Tippmann, E. (2018). Becoming a multinational enterprise: Using industry recipes to achieve rapid multi-nationalization. Journal of International Business Studies, 49(4), 473-495.

Morey, A. (2003). Hollywood Outsiders: The Adaptation of the Film Industry, 1913-1934. U of Minnesota Press.

Motion Picture Association of America (MPAA). (2017). Theatrical and home entertainment market environment. Available online at: https:/www.mpaa.org/wp-content/uploads/2018/04/MPAA-THEME-Report-2017_Final.pdf [Accessed December 24, 2018].

Newcomer, K. E., Hatry, H. P., \& Wholey, J. S. (2015). Conducting semi-structured interviews. Handbook of practical program evaluation, 492.

Pereverza, K., Pasichnyi, O., Lazarevic, D., \& Kordas, O. (2017). Strategic planning for sustainable heating in cities: a morphological method for scenario development and selection. Applied Energy, 186, 115-125.

Pettigrew, A. M. (1990). Longitudinal field research on change: Theory and practice. Organization Science, 1(3), 267292.

Phillips, M. E. (1994). Industry mindsets: Exploring the cultures of two macro-organizational settings. Organization Science, 5(3), 384-402.

Porter, M. E. (1980). Industry structure and competitive strategy: Keys to profitability. Financial Analysts Journal, 36(4), 30-41.

Porter, M. E. (1985). The competitive advantage: Creating and sustaining superior performance. New York: Free Press.

Porter, M. E. (1996). What is Strategy?. Harvard Business Review. 74(6): 61-78.

Porter, M. E., \& Rivkin, J. W. (2000). Industry Transformation. Harvard Business School (No. 9, pp. 701-008). Publishing.

Ramirez, R., Osterman, R., Gronquist, D., (2013). Scenarios and early warnings as dynamic capabilities to frame managerial attention. Technological Forecasting and Social Change. 80, 825-838.

Ross, Steven J. "How Hollywood Became Hollywood: Money, Politics, and Movies." In Metropolis in the Making: Los Angeles in the 1920s. Ed. Sitton, Tom and William Deverell. Berkeley: University of California Press, 2001. 255276.

Rowley, J. (2012). Conducting research interviews. Management Research Review, 35(3/4), 260-271.

Sabatier, V., Mangematin, V., \& Rousselle, T. (2010). From recipe to dinner: business model portfolios in the European biopharmaceutical industry. Long Range Planning, 43(2-3), 431-447.

Sandström, C., Magnusson, M., \& Jörnmark, J. (2009). Exploring factors influencing incumbents' response to disruptive innovation. Creativity and Innovation Management, 18(1), 8-15.).

Sarpong, D., Maclean, M., \& Davies, C. (2013). A matter of foresight: How practices enable (or impede) organizational foresightfulness. European Management Journal, 31(6), 613-625. 
Schoemaker, P. J. (1993). Multiple scenario development: Its conceptual and behavioral foundation. Strategic Management Journal, 14(3), 193-213.

Schoemaker, P. J. (1995). Scenario planning: a tool for strategic thinking. Sloan Management Review, 36(2), 25-50.

Secor, A. (2010). Social surveys, interviews, and focus groups. Research methods in Geography. Eds. Gomez, B. and J. Jones, 3, 194-205.

Singleton, R. A., \& Straits, B. C. (2002). Survey interviewing. Handbook of interview research: Context and method, 59-82.

Sirmon, D. G., \& Hitt, M. A. (2009). Contingencies within dynamic managerial capabilities: Interdependent effects of resource investment and deployment on firm performance. Strategic Management Journal, 30(13), 1375-1394.

Skule, S. (1996). From skills to organizational practice: A study of the relation between vocational education and organizational learning in the food processing industry.

Smith, K. G., Ferrier, W. J., \& Grimm, C. M. (2001). King of the hill: Dethroning the industry leader. Academy of Management Perspectives, 15(2), 59-70.

Spender, J. C. (1989). Industry Recipes. Oxford: Basil Blackwell.

Spender, J. C. (1996). Making knowledge the basis of a dynamic theory of the firm. Strategic Management Journal, 17(S2), 45-62.

Spender, J. C. (2001). Business policy and strategy as a professional field. Rethinking Strategy. London: Sage.

Trumpbour, J. (2007). Selling Hollywood to the world: US and European struggles for mastery of the global film industry, 1920-1950. Cambridge University Press.

Vakratsas, D., \& Ma, Z. (2009). Firm adaptiveness and performance heterogeneity: the case of sales-advertising dynamics in an evolving product market. Journal of Evolutionary Economics, 19(1), 21.

Van der Heijden, K. (2000). Scenarios and forecasting: two perspectives. Technological Forecasting and social Change, 65(1), 31-36.

Van der Heijden, K., Bradfield, R., Burt, G., Cairns, G., \& Wright, G. (2002). The sixth sense: Accelerating organizational learning with scenarios. John Wiley \& Sons.

Van der Merwe, L. (2008). Scenario-based strategy in practice: a framework. Advances in Developing Human Resources, 10(2), 216-239.

Vannoni, M. (2015). What are case studies good for? Nesting comparative case study research into the lakatosian research program. Cross-Cultural Research, 49(4), 331-357.

Varum, C. A., \& Melo, C. (2010). Directions in scenario planning literature - A review of the past decades. Futures, 42(4), 355-369.

Vecchiato, R. (2017). Disruptive innovation, managerial cognition, and technology competition outcomes. Technological Forecasting and Social Change, 116, 116-128.

Verwater-Lukszo, Z. (1998). A practical approach to recipe improvement and optimization in the batch processing industry. Computers in Industry, 36(3), 279-300. 
Volkery, A., \& Ribeiro, T. (2009). Scenario planning in public policy: understanding use, impacts and the role of institutional context factors. Technological Forecasting and Social Change, 76(9), 1198-1207.

Wack, P. (1985b). Scenarios: shooting the rapids. Harvard Business Review. 6, 139-150.

Wack, P. (1985a). Scenarios: uncharted waters ahead. Harvard Business Review. 5, 72-89.

Walsh, P. R. (2005). Dealing with the uncertainties of environmental change by adding scenario planning to the strategy reformulation equation. Management Decision, 43(1), 113-122.

Wasson, C. (2000). Ethnography in the field of design. Human Organization, 377-388.

Wendt, A. E. (1987). The agent-structure problem in international relations theory. International Organization, 41(3), 335-370.

Whitley, R. (2004). The social construction of organizations and markets: The comparative analysis of business recipes. The New Economic Sociology, 162-187.

Windeler, A., \& Sydow, J. (2001). Project networks and changing industry practices collaborative content production in the German television industry. Organization Studies, 22(6), 1035-1060.

Wilkinson, A., \& Kupers, R. (2014). The essence of scenarios: learning from the Shell experience. Amsterdam University Press.

Wright, A., (2005). The role of scenarios as prospective sensemaking devices. Management Decision, 43. 86-101.

Wright, G., Bradfield, R., \& Cairns, G. (2013). Does the intuitive logics method-and its recent enhancements-produce "effective" scenarios?. Technological Forecasting and Social Change, 80(4), 631-642.

Yin, R. K. (2003). Case study research: Design and methods. 


\subsection{APPENDIX}

Table 1. Studio association key

\begin{tabular}{|l|l|}
\hline \multicolumn{2}{|c|}{ STUDIO ASSOCATIONS KEY } \\
\hline Incumbent Major Studio & IMaj \\
\hline Incumbent Minor Studio & IMin \\
\hline Challenger Major Studio & ChMaj \\
\hline Challenger Minor Studio & ChMin \\
\hline
\end{tabular}

Table 2. Industry survey questions

\begin{tabular}{|l|l|}
\hline \multicolumn{2}{|c|}{ SURVEY QUESTIONS } \\
\hline 1. & Describe the Hollywood film industry and the firms within it \\
\hline 2. & How are feature films made within the industry? \\
\hline 3. & What factors contribute to the success or failure of film projects? \\
\hline 4. & What is the competitive landscape like in the Hollywood film industry? \\
\hline 5. & What challenges does the industry face in the future? \\
\hline
\end{tabular}

Table 3. Profiles of interview participants from incumbent and challenger studios

\begin{tabular}{|l|l|l|c|c|c|}
\hline Studio Profile & $\begin{array}{l}\text { Interview } \\
\text { Participant }\end{array}$ & Position & Age & $\begin{array}{c}\text { Time in } \\
\text { Industry }\end{array}$ & Gender \\
\hline & 1 & CFO & 58 & 31 years & $\mathrm{M}$ \\
\hline $\begin{array}{l}\text { Incumbent Major } \\
\text { Studio (IMaj) }\end{array}$ & 2 & COS-Chairman and CEO & 35 & 13 years & $\mathrm{M}$ \\
\hline & 3 & VP-Content Management & 43 & 10 years & $\mathrm{M}$ \\
\hline & 4 & $\begin{array}{l}\text { Director-Business Development } \\
\& \text { Strategic Planning }\end{array}$ & 35 & 8 years & $\mathrm{M}$ \\
\hline & 5 & $\begin{array}{l}\text { Director-Film Strategy \& } \\
\text { Operations }\end{array}$ & 41 & 15 years & $\mathrm{M}$ \\
\hline
\end{tabular}




\begin{tabular}{|c|c|c|c|c|c|}
\hline & 6 & $\begin{array}{l}\text { Director-Financial Systems \& } \\
\text { Planning }\end{array}$ & 45 & 17 years & $\mathrm{M}$ \\
\hline & 7 & $\begin{array}{l}\text { Manager-Marketing and Brand } \\
\text { Assistance }\end{array}$ & 35 & 11 years & $\mathrm{F}$ \\
\hline & 8 & Director-Digital Media & 37 & 11 years & $\mathrm{M}$ \\
\hline \multirow{8}{*}{$\begin{array}{l}\text { Challenger Major } \\
\text { Studio (ChMaj) }\end{array}$} & 1 & CEO \& Founder & 66 & 35 years & $\mathrm{M}$ \\
\hline & 2 & Pres. Marketing & 52 & 15 years & $\mathrm{F}$ \\
\hline & 3 & $\mathrm{COO}$ & 61 & 25 years & $\mathrm{M}$ \\
\hline & 4 & $\begin{array}{l}\text { EVP Motion Picture Business \& } \\
\text { Legal Affairs }\end{array}$ & 45 & 21 years & $\bar{M}$ \\
\hline & 5 & $\mathrm{CFO}$ & 48 & 23 years & M \\
\hline & 6 & Director-Marketing & 42 & 12 years & $\mathrm{M}$ \\
\hline & 7 & Creative Development Executive & 43 & 15 years & $\mathrm{F}$ \\
\hline & 8 & Character \& Lead Animator & 35 & 13 years & M \\
\hline \multirow[t]{8}{*}{$\begin{array}{l}\text { Incumbent Minor } \\
\text { Studio (IMin) }\end{array}$} & 1 & Pres. Domestic Distribution & $\begin{array}{c}\text { Mid } \\
50 \mathrm{~s}\end{array}$ & 30 years & M \\
\hline & 2 & $\begin{array}{l}\text { EVP Strategic Planning \& } \\
\text { Operations }\end{array}$ & 41 & 15 years & $\mathrm{F}$ \\
\hline & 3 & $\begin{array}{l}\text { SVP Strategic Planning/Bus. } \\
\text { Development }\end{array}$ & 42 & 17 years & $\mathrm{M}$ \\
\hline & 4 & SVP Distribution \& Marketing & 41 & 18 years & $\mathrm{M}$ \\
\hline & 5 & EVP Domestic Distribution & 55 & 25 years & $\bar{M}$ \\
\hline & 6 & $\begin{array}{l}\text { Manager-Exhibitor Relations \& } \\
\text { Theatrical Distribution }\end{array}$ & 31 & 8 years & $\mathrm{F}$ \\
\hline & 7 & $\begin{array}{l}\text { Manager-International } \\
\text { Distribution }\end{array}$ & 32 & 9 years & $\mathrm{F}$ \\
\hline & 8 & VP Production/Development & 34 & 10 years & $\bar{M}$ \\
\hline \multirow[t]{4}{*}{$\begin{array}{l}\text { Challenger Minor } \\
\text { Studio (ChMin) }\end{array}$} & 1 & CEO & 64 & 38 years & M \\
\hline & 2 & President & 38 & 13 years & $\bar{M}$ \\
\hline & 3 & Founder/Principle & 46 & 20 years & $\mathrm{M}$ \\
\hline & 4 & $\begin{array}{l}\text { Creative Writer \& Content } \\
\text { Manager }\end{array}$ & 30 & 6 years & $\mathrm{M}$ \\
\hline
\end{tabular}




\begin{tabular}{|c|c|l|c|c|c|}
\hline & 5 & $\begin{array}{l}\text { Business Manager/COS to } \\
\text { Founder \& COB }\end{array}$ & 38 & 13 years & M \\
\hline & 6 & $\begin{array}{l}\text { Business Operations } \\
\text { Manager/Creative Assistant }\end{array}$ & 30 & 7 years & $\mathrm{M}$ \\
\hline
\end{tabular}

Figure 1. Industry recipe factors of the Hollywood Film Industry

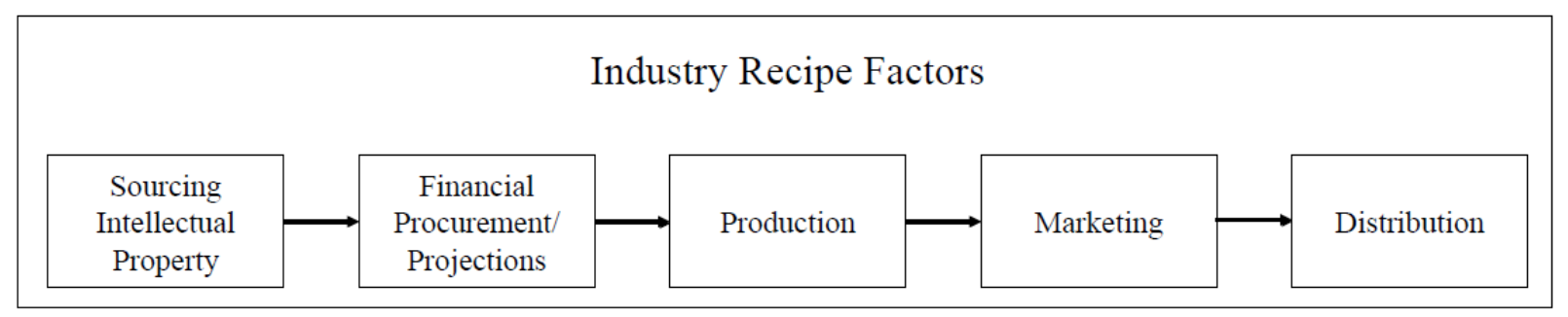

Figure 2. Industry recipes and the intuitive logics approach

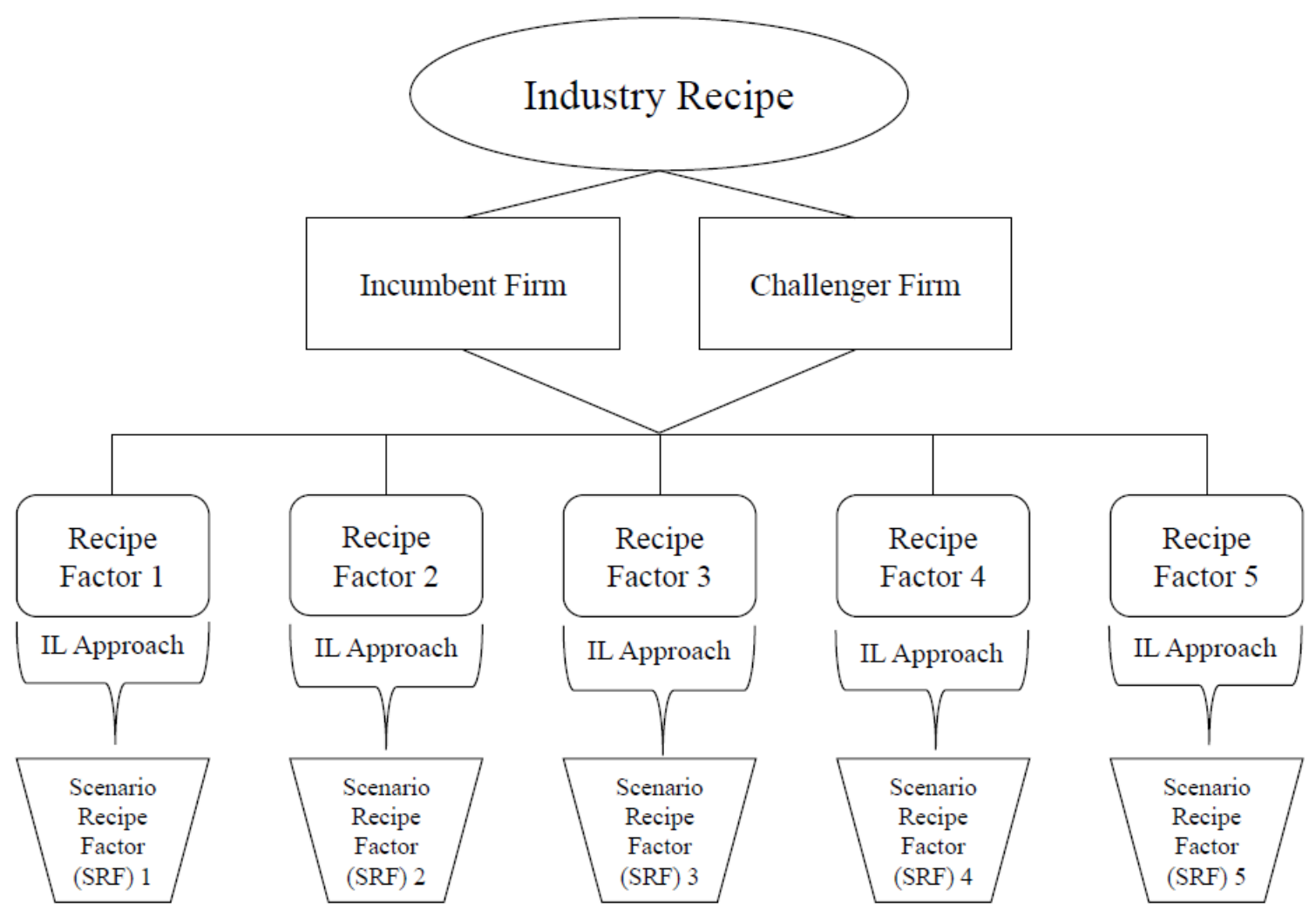


Figure 3. Synthesizing industry recipes and the IL approach

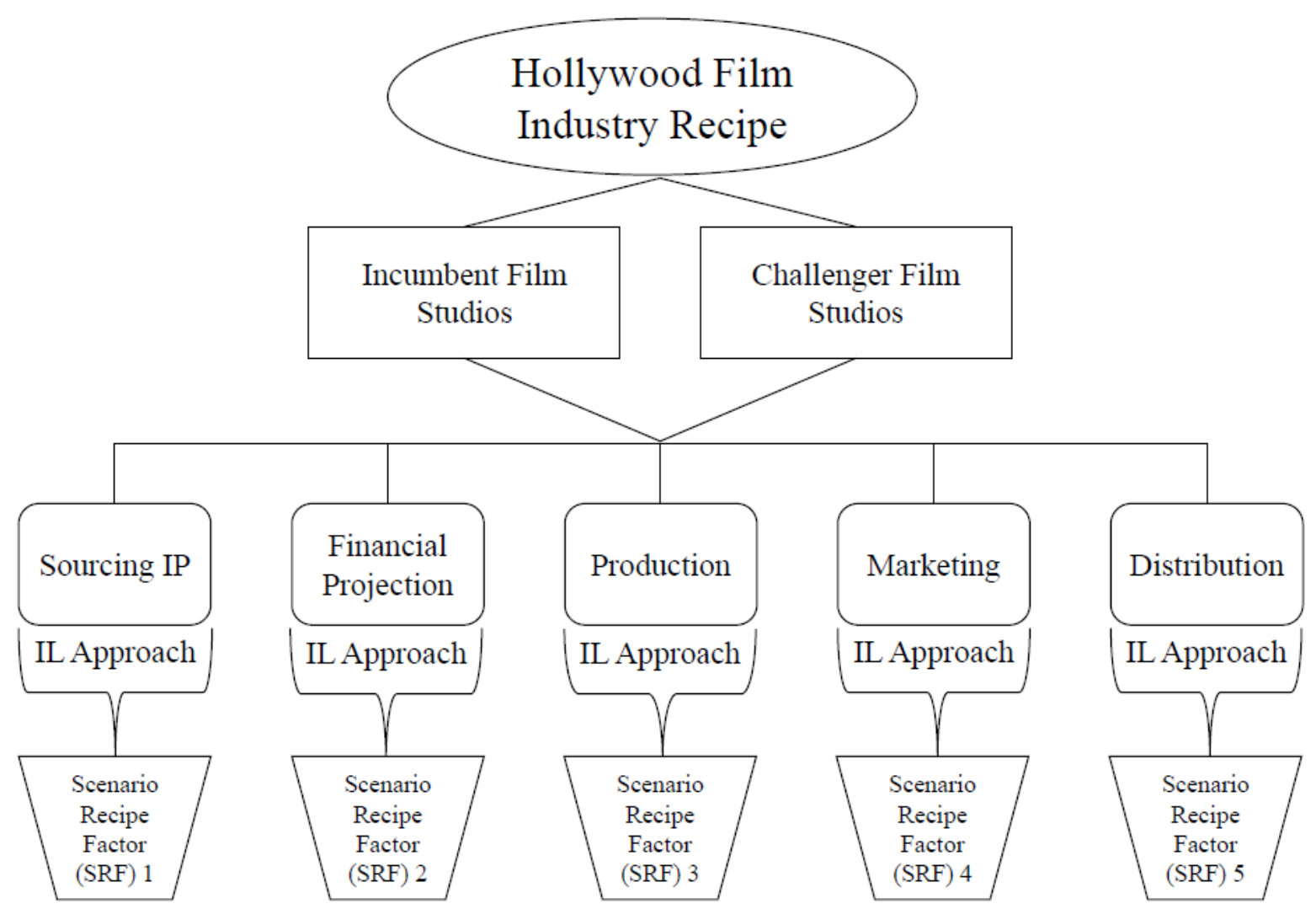


Table 4. Sample set of evidence illustrating the comparable factors between studios

\begin{tabular}{|c|c|c|c|c|c|}
\hline Recipe Factor & Sourcing/IP & Financing & Producing & Marketing & Distribution \\
\hline (IMaj) & $\begin{array}{l}\text { "Well from a studio perspective, they } \\
\text { usually have a team of production } \\
\text { executives who then work with what } \\
\text { is called 'term deal producers'. And } \\
\text { they all have budgets that allow them } \\
\text { to go out and buy material. Whether } \\
\text { it's a book, a magazine article, just a } \\
\text { pitch from writers, whether it's } \\
\text { turning intellectual property into a } \\
\text { movie - ideas can come from } \\
\text { anywhere."-Interviewee A2 }\end{array}$ & $\begin{array}{l}\text { "You start out with putting } \\
\text { together comps. So comps } \\
\text { based on the genre, comps } \\
\text { based on the director, comps } \\
\text { based on the star or stars, and } \\
\text { then there is enough data out } \\
\text { there that you can kind of get } \\
\text { a pretty good trend line as to } \\
\text { how it will perform. - } \\
\text { Interviewee A1 }\end{array}$ & $\begin{array}{l}\text { "The creative people feeling like, 'okay } \\
\text { this project looks interesting'. The } \\
\text { project in itself was like the entire } \\
\text { package - the script, the visuals, what } \\
\text { the idea of the director was for the } \\
\text { movie, the talent that was attached to the } \\
\text { movie - all of the package, more or less, } \\
\text { made sense."-Interviewee A4 }\end{array}$ & $\begin{array}{l}\text { "It really comes down to creative } \\
\text { execution. But at the same time, it also } \\
\text { does come down to marketing." - } \\
\text { Interviewee A2 }\end{array}$ & $\begin{array}{l}\text { "Let's look at from the studio side as } \\
\text { opposed to a specific film. The studio } \\
\text { side, you have to, if you're distributing } \\
\text { films, you have to have a certain } \\
\text { amount of people and infrastructure to } \\
\text { distribute that film distribution." - } \\
\text { Interviewee A6 }\end{array}$ \\
\hline (ChMaj) & $\begin{array}{l}\text { "If you establish the correct value of } \\
\text { an idea and develop it at an } \\
\text { appropriate production budget, you } \\
\text { will mitigate the risk of the resulting } \\
\text { film." -Interviewee B1 }\end{array}$ & $\begin{array}{l}\text { "They need a big summer } \\
\text { tent-pole because that's } \\
\text { where you're making the } \\
\text { biggest percent of your box } \\
\text { office from the year." - } \\
\text { Interviewee B4 }\end{array}$ & $\begin{array}{l}\text { "If an actor is miscast, a } \\
\text { cinematographer doesn't capture the } \\
\text { mood, an editor doesn't get the pace } \\
\text { right, then everything else can be top- } \\
\text { notch, but the film just won't work." - } \\
\text { Interviewee B1 }\end{array}$ & $\begin{array}{l}\text { "There is testing that the studio does, } \\
\text { like they'll kind of screen relatively } \\
\text { early cuts of the movie and say like, } \\
\text { maybe like a year before it's scheduled } \\
\text { to come out -they'll start having } \\
\text { regular test screenings with test } \\
\text { audiences." -Interviewee B7 }\end{array}$ & $\begin{array}{l}\text { "Everyone knows when everyone } \\
\text { else's movies are being released } \\
\text { because studios sort of announce that } \\
\text { way ahead of time. They're reserving } \\
\text { their dates, especially in the summer... } \\
\text { every distribution guy has that } \\
\text { information and they're either working } \\
\text { around that."-Interviewee B6 }\end{array}$ \\
\hline Recipe Factor & Sourcing/IP & Financing & Producing & Marketing & Distribution \\
\hline (IMin) & $\begin{array}{l}\text { "We have a team of people here that } \\
\text { do something called coverage. And } \\
\text { they're the ones, so they actually read } \\
\text { the scripts, and look at the scripts } \\
\text { critically, basically, in terms of, is } \\
\text { this something that you can produce } \\
\text { into a film? Is this something where } \\
\text { the story is, how good is the story."- } \\
\text { Interviewee C3 }\end{array}$ & $\begin{array}{l}\text { "There's too much money at } \\
\text { risk if you do finance } \\
\text { something that doesn't work. } \\
\text { So it's a little bit of } \\
\text { experience, it's a little bit of } \\
\text { knowing the right people to } \\
\text { finance a movie." - } \\
\text { Interviewee C1 }\end{array}$ & $\begin{array}{l}\text { "It's definitely about the creative take on } \\
\text { a movie, the casting, and that's super } \\
\text { important, but if a movie doesn't work } \\
\text { economically, the company will fail. } \\
\text { So, it really is not getting swayed by the } \\
\text { creative side, "Oh, yeah, let's take a } \\
\text { chance."-Interviewee C2 }\end{array}$ & $\begin{array}{l}\text { "But it also just means, you know, you } \\
\text { get wrapped up when you work in this } \\
\text { industry of thinking of movies as good } \\
\text { and bad, based on how marketable they } \\
\text { are, how accessible they are to the } \\
\text { public, you know." -Interviewee C4 }\end{array}$ & $\begin{array}{l}\text { "First I need to figure out how exactly } \\
\text { we're going to release the movie. Is it } \\
\text { going to be a wide release? A limited } \\
\text { release? A platform? Etc. When are we } \\
\text { going to release it? What date? And } \\
\text { then make sure that we select the } \\
\text { appropriate locations - the theaters } \\
\text { across the country. And that's what I } \\
\text { do. We light up the film to exhibitors } \\
\text { across the country."-Interviewee C5 }\end{array}$ \\
\hline (ChMin) & $\begin{array}{l}\text { "It becomes much more, much less } \\
\text { about, "is this IP like great... as far as } \\
\text { brand." It's really about the IP } \\
\text { around the script." -Interviewee D3 }\end{array}$ & $\begin{array}{l}\text { "If you're a studio you can... } \\
\text { buy your way out of } \\
\text { uncertainty... put enough } \\
\text { money behind it to lessen } \\
\text { the... uh.... Probability of } \\
\text { failure... um... and then in } \\
\text { the independent world you } \\
\text { live with it, that's your life." } \\
\text {-Interviewee D1 }\end{array}$ & $\begin{array}{l}\text { "That's what a producer does, is } \\
\text { generally they find the script, they bring } \\
\text { the script to the director or they bring it } \\
\text { to a casting agent and that agent gets in } \\
\text { touch with a director and they're the } \\
\text { ones going through the meetings and } \\
\text { what have you. So I'm saying generally } \\
\text { the producers are the driving forces } \\
\text { behind it." -Interviewee D4 }\end{array}$ & $\begin{array}{l}\text { "Usually what we have to do is have } \\
\text { an intern read and if they like it and } \\
\text { regardless they'll give it coverage } \\
\text { which is commentary, synopsis, } \\
\text { marketability and whether or not this is } \\
\text { a project that would interest the } \\
\text { company."-Interviewee D4 }\end{array}$ & $\begin{array}{l}\text { "Distribution is the broken part of the } \\
\text { business right now. The studios still } \\
\text { have it wired, but I think the landscape } \\
\text { has changed so much that unless the } \\
\text { studios adapt, we're now seeing } \\
\text { content that's available directly to } \\
\text { consumer." -Interviewee D2 }\end{array}$ \\
\hline
\end{tabular}


